\title{
Antiplatelet effects of prostacyclin analogues: Which one to choose in case of thrombosis or bleeding?
}

\author{
Sylwester P. Rogula ${ }^{1 *}$, Hubert M. Mutwil ${ }^{1 *}$, Aleksandra Gąsecka ${ }^{1}$, \\ Marcin Kurzyna $^{2}$, Krzysztof J. Filipiak ${ }^{1}$ \\ ${ }^{1} 1^{\text {st }}$ Chair and Department of Cardiology, Medical University of Warsaw, Poland \\ ${ }^{2}$ Department of Pulmonary Circulation, Thromboembolic Diseases and Cardiology, \\ Center of Postgraduate Education Medical, European Health Center Otwock, Poland
}

\begin{abstract}
Prostacyclin and analogues are successfully used in the treatment of pulmonary arterial hypertension $(P A H)$ due to their vasodilatory effect on pulmonary arteries. Besides vasodilatory effect, prostacyclin analogues inhibit platelets, but their antiplatelet effect is not thoroughly established. The antiplatelet effect of prostacyclin analogues may be beneficial in case of increased risk of thromboembolic events, or undesirable in case of increased risk of bleeding. Since prostacyclin and analogues differ regarding their potency and form of administration, they might also inhibit platelets to a different extent. This review summarizes the recent evidence on the antiplatelet effects of prostacyclin and analogue in the treatment of PAH, this is important to consider when choosing the optimal treatment regimen in tailoring to an individual patients' needs. (Cardiol J 2021; 28, 6: 954-961)
\end{abstract}

Key words: prostacyclin analogues, pulmonary arterial hypertension, platelets, antiplatelet effect, thrombosis, bleeding

\section{Introduction}

Since 1935 when prostaglandin was isolated for the first time [1], many scientists have focused on a thorough study of arachidonic acid transformation products and their various biological functions. One of the major prostaglandins is prostacyclin $\left(\mathrm{PGI}_{2}\right)$, which was discovered by John R. Vane in 1976 [2]. Endogenous $\mathrm{PGI}_{2}$ binds to prostacyclin receptor (IP) on pulmonary vessels smooth muscle cells and platelets. Activated IP receptor induces production of cyclic adenosine monophosphate (cAMP), which activates protein kinase A (PKA) and results in smooth muscle relaxation, inhibition of platelet aggregation and reduction of cell proliferation [3]. Synthetic $\mathrm{PGI}_{2}$ analogues have a similar effect on cells as does natural $\mathrm{PGI}_{2}$. Nowadays, $\mathrm{PGI}_{2}$ and its analogues are being used due to their vasodilating, antithrombotic and an- tiproliferative effects [4]. The main indication for $\mathrm{PGI}_{2}$ and analogues is advanced pulmonary arterial hypertension (PAH) and peripheral vascular disorders [5]. Treprostinil, iloprost and beraprost are the most frequently used prostacyclin analogues [4]. Selexipag is a non-prostanoid IP receptor agonist and a promising new alternative for classic $\mathrm{PGI}_{2}$ analogues [6].

As $\mathrm{PGI}_{2}$ analogues vary depending on the way of administration, pharmacokinetics, binding and affinity for IP receptors, they may also inhibit platelets to a different extent [5]. These differences result in various side effects and complications associated with the of $\mathrm{PGI}_{2}$ analogues and implicate the need to tailor the treatment according to a patient's individual needs. Because the intensity of antiplatelet effect of $\mathrm{PGI}_{2}$ analogues have not been clarified, choosing the best therapeutic option for individual patients at high risk, or with

Address for correspondence: Dr. Aleksandra Gąsecka, $1^{\text {st }}$ Chair and Department of Cardiology, Medical University of Warsaw, ul. Banacha 1a, 02-097 Warszawa, Poland, tel: +48 518343 599, e-mail: aleksandra.gasecka@wum.edu.pl

Received: 1.07.2020 Accepted: 12.10.2020 Early publication date: 9.11.2020

*Sylwester P. Rogula and Hubert M. Mutwil share the first authorship.

This article is available in open access under Creative Common Attribution-Non-Commercial-No Derivatives 4.0 International (CC BY-NC-ND 4.0) license, allowing to download articles and share them with others as long as they credit the authors and the publisher, but without permission to change them in any way or use them commercially. 
Table 1. Receptors for prostacycline and its analogues on platelets.

\begin{tabular}{lccc}
\hline Receptor & G-protein coupled & Effect of activation & Agonist \\
\hline $\mathrm{DP}[25,49]$ & $\mathrm{Gs}$ & cAMP $\uparrow$ & epoprostenol, iloprost, treprostinil \\
$\mathrm{IP}[23,24,25,48]$ & $\mathrm{Gs}>\mathrm{Gq}$ & cAMP $\uparrow$ & epoprostenol, iloprost, treprostinil, \\
& $\mathrm{Gq}>\mathrm{Gs}=\mathrm{Gi}$ & $\mathrm{cAMP} \downarrow \downarrow$ & beraprost, selexipag \\
$\mathrm{TP}[22]$ & $\mathrm{Gi}>\mathrm{Gq}=\mathrm{Gs}$ & $\mathrm{cAMP} \downarrow$ & iloprost \\
$\mathrm{EP}_{3}[23,24]$ & & epoprostenol, iloprost, beraprost \\
\hline
\end{tabular}

cAMP - cyclic adenosine monophosphate

a history of thrombosis or bleeding remains challenging. This review (i) describes the role of $\mathrm{PGI}_{2}$ in hemostasis, (ii) summarizes the recent evidence on the antiplatelet effect of $\mathrm{PGI}_{2}$ analogues in the treatment of PAH, and (iii) provides recommendations regarding the choice of the optimal $\mathrm{PGI}_{2}$ analogue in case of thrombosis or bleeding.

\section{Role of prostacyclin in hemostasis}

$\mathrm{PGI}_{2}$ plays a prominent role in hemostasis, both due to its effect on vascular endothelium, smooth muscle cells and platelets. When a blood vessel wall is damaged, collagen and von Willebrand factor ( $\mathrm{vWF}$ ) are exposed enabling platelets adherence to the subendothelium and granule content release [7]. Thromboxane A2 (TxA2) and adenosine diphosphate (ADP) released from, or produced by activated platelets contribute to platelet aggregation, which temporarily repairs vascular injury. ADP also induces the conformation change of glycoprotein (GP) IIb/IIIa type receptor, allowing binding of fibrinogen to GP IIb/IIIa and cross-linking of the adjacent platelets. The released calcium ions $\left(\mathrm{Ca}^{2+}\right)$ bind to phospholipids that are exposed on the surface of activated platelets and provide a co-factor for the assembly of coagulation factors, facilitating thrombus formation [8]. The processes of primary hemostasis are counteracted by $\mathrm{PGI}_{2}$, which is a thromboxane receptor antagonist. The main task of $\mathrm{PGI}_{2}$ is to limit the coagulation to the small area where it is needed, and to sustain patency of the blood vessel [9].

Following platelet-rich thrombus formation, further steps include activation of plasma coagulation factors and formation of crosslinked fibrin by two pathways: extrinsic and intrinsic. The extrinsic pathway is activated by the tissue factor (TF) exposed by vessel injury and released from platelets, which is necessary for activation of factor VII. The complex consisting of $\mathrm{Ca}^{2+}$, TF and factor VII can then activate factor $\mathrm{X}$, which starts the common pathway [10]. In the intrinsic pathway, factor XII is activated by contact with the damaged vascular surface, high molecular weight kininogen and kallikrein. This complex initiates the cascade of activation of factor XI and IX. The next step is the activation of factor X, which starts the common pathway. Finally, factors $\mathrm{Xa}$, Va and $\mathrm{Ca}^{2+}$ form a complex that converts prothrombin to thrombin, which then converts fibrinogen to fibrin to form a fibrin polymer. After that, plasma transglutaminase (factor XIII) stabilises the clot. Although $\mathrm{PGI}_{2}$ is not directly involved in clot formation, appropriate platelet aggregation is a prerequisite for clotting. Hence, $\mathrm{PGI}_{2}$ may affect secondary hemostasis and clot formation as well.

\section{Prostacyclin receptors}

Prostacyclin receptors (IP) are seven-transmembrane $\mathrm{G}$ protein-coupled receptors, exposed on vascular smooth muscle cells and platelets [11]. The main characteristics of the IP receptors are summarized in Table 1 . There are four types of IP receptors on platelets: IP, DP, TP, and $\mathrm{EP}_{3}$. The IP and DP receptors have anti-aggregatory effects, whereas the $\mathrm{TP}, \mathrm{EP}_{3}$ have pro-aggregatory effects [12].

Figure 1 shows the function of IP and DP receptors. The IP receptor works in two ways. First, it activates Gs protein, associated with adenylyl cyclase (AC) to produce cAMP [13], resulting in phosphorylation of the vasodilator-stimulated phosphoprotein (VASP) by protein kinase A. VASP suppresses the activation of the membrane GP IIb/ /IIIa, thus preventing platelet aggregation [14]. Second, IP activates Gq protein [15]. Activation of $\mathrm{Gq}$ protein stimulates phospholipase $\mathrm{C}$ to synthesize second messengers which increases the intracellular $\mathrm{Ca}^{2+}$ concentration. Increases $\mathrm{Ca}^{2+}$ reduces the amount of cAMP, which might facilitate platelet aggregation [16]. However, the Gq-mediated effect of $\mathrm{PGI}_{2}$ is less significant, so that the net effect of $\mathrm{PGI}_{2}$ binding to IP receptor is anti-aggregatory. The DP receptor activates Gs protein only, therefore raising the intracellular cAMP concentration and potentiating platelet inhibition. 


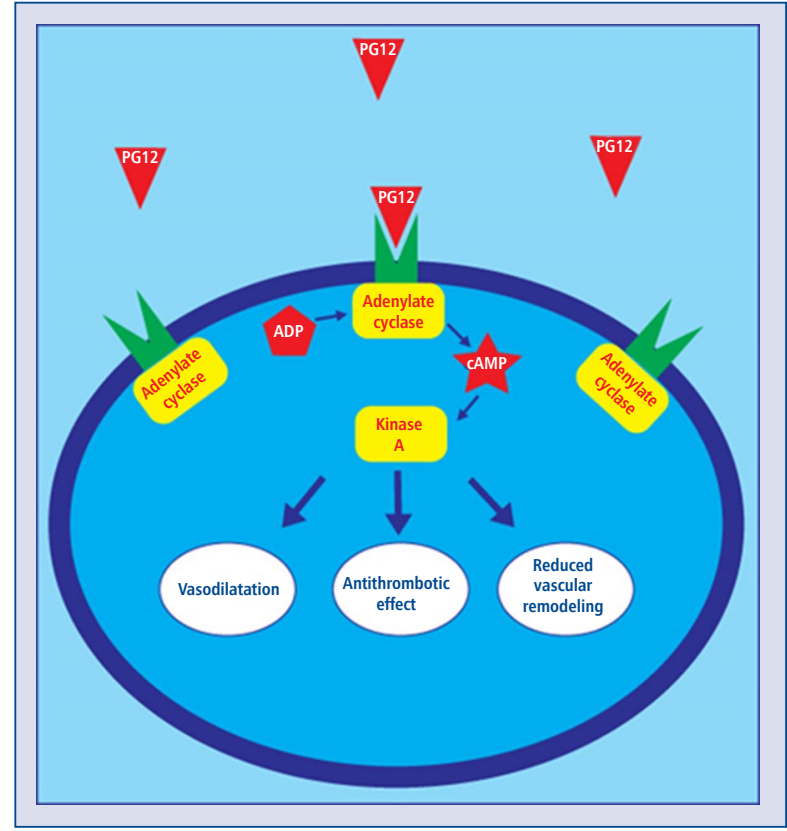

Figure 1. Effects of activation of IP and DP for prostacyclin receptors on platelets; abbreviations - see text.

TP receptor affects the activity of three $\mathrm{G}$ proteins: Gq protein strongly, and both $\mathrm{Gi}$ and $\mathrm{Gs}$ in a less significant way. Since the effect of TP on $\mathrm{Gi}$ and $\mathrm{Gs}$ are contradictory, the net effect of this receptor is executed via $\mathrm{Gq}$ protein, resulting in reduced cAMP concentration and a pro-aggregatory effect $[17,18]$. However, the TP receptor can also form heterodimers with the TP receptor [19]. The IP-TP heterodimer function is similar to the IP receptor (anti-aggregatory), since the TP compound is overpowered. The $\mathrm{EP}_{3}$ receptor activates the same $\mathrm{G}$ proteins as TP receptor, but most significantly the Gi protein, resulting in reduced cAMP and platelet aggregation [20].
Due to the fact that the IP receptors have both anti- and pro-aggregatory modes of action, the net clinical effect (thrombosis and bleeding) of $\mathrm{PGI}_{2}$ and analogues are difficult to predict. Recently, there has been a search for a substance, which would specifically bind to the IP receptor, resulting in the introduction of selexipag [21]. Selexipag has a much higher affinity to platelet-inhibiting receptors (IP and $\mathrm{DP}$ ), and none to platelet-activating receptors (TP and $\mathrm{EP}_{3}$ ). However, whether this specificity is associated with a higher bleeding tendency remains to be investigated.

\section{Differences in pharmacodynamics and pharmacokinetics of prostacyclin and analogues}

$\mathrm{PGI}_{2}$ and analogues are available in parenteral and oral form. Different routes of administration result in differing pharmacokinetics of each drug. $\mathrm{PGI}_{2}$ and analogues are primarily metabolized by cytochromes $\mathrm{P} 450$ in the liver, especially by CYP2C8. Selexipag is the only $\mathrm{PGI}_{2}$ analogue which has an active metabolite. Short half-life of $\mathrm{PGI}_{2}$ and analogues often requires continuous infusions by external or implantable intravenous infusion pumps. Epoprostenol, iloprost and beraprost bind both to the antiaggregatory IP and DP receptors and to the proaggregatory $\mathrm{EP}_{3}$ [22-24]. Iloprost also binds to the pro-aggregatory TP receptor [22]. Treprostinil binds only to the anti-aggregatory IP and DP receptors [25]. Selexipag is a specific IP receptor agonist [24]. Consequently, the route of administration, metabolism of $\mathrm{PGI}_{2}$ and analogues and their binding profile may define their side effects, including thrombosis and bleeding. The comparison of pharmacokinetics, pharmacodynamics and side effects of the most commonly used drugs $\mathrm{PGI}_{2}$ analogue are thoroughly summarized in Table 2.

Table 2. Comparison of pharmacokinetics, side effects, contraindications of the most commonly used drugs which target the prostacyclin pathway.

\begin{tabular}{|c|c|c|c|c|}
\hline Drug $^{1}$ & $\begin{array}{c}\text { Route of } \\
\text { administration }\end{array}$ & Pharmacokinetics & $\begin{array}{l}\text { Side effects related } \\
\text { to the route of } \\
\text { administration }\end{array}$ & $\begin{array}{l}\text { Side effects not related } \\
\text { to the route of } \\
\text { administration }\end{array}$ \\
\hline $\begin{array}{l}\text { Epoprostenol } \\
{[50,51]}\end{array}$ & $\begin{array}{l}\text { i.v. infusion } \\
\left(\text { Flolan }{ }^{\circledR}\right. \\
\left.\text { Veletri }^{\circledR}\right)^{\prime}\end{array}$ & $\begin{array}{c}\text { Bioavailability: } 100 \% \\
\text { Metabolism: } \\
\text { Spontaneous } \\
\text { degradation in blood } \\
\text { Enzymatic } \\
\text { degradation } \\
\text { in the liver } \\
\text { Elimination: } \\
\text { Mainly urine (84\%) } \\
\mathrm{T} 1 / 2<6 \text { min }\end{array}$ & $\begin{array}{c}\text { Bleeding } \\
\text { Infection } \\
\text { (catheter-related) } \\
\text { Malfunction of the } \\
\text { infusion pump } \\
\text { Pain } \\
\text { Sepsis } \\
\text { Thromboembolic } \\
\text { event }\end{array}$ & $\begin{array}{c}\text { Anorexia } \\
\text { Diarrhoea } \\
\text { Dizziness } \\
\text { Flushing } \\
\text { Headache } \\
\text { Hypotension } \\
\text { Jaw pain } \\
\text { Musculoskeletal pain } \\
\text { Nausea } \\
\text { Vomiting } \\
\text { Tachycardia } \\
\text { Vasodilatation }\end{array}$ \\
\hline
\end{tabular}


Table 2 (cont.). Comparison of pharmacokinetics, side effects, contraindications of the most commonly used drugs which target the prostacyclin pathway.

\begin{tabular}{|c|c|c|c|c|}
\hline Drug $^{1}$ & $\begin{array}{c}\text { Route of } \\
\text { administration }\end{array}$ & Pharmacokinetics & $\begin{array}{l}\text { Side effects related } \\
\text { to the route of } \\
\text { administration }\end{array}$ & $\begin{array}{l}\text { Side effects not related } \\
\text { to the route of } \\
\text { administration }\end{array}$ \\
\hline \multirow[t]{4}{*}{$\begin{array}{l}\text { Treprostinil } \\
{[52,53,54]}\end{array}$} & $\begin{array}{l}\text { s.c. infusion }{ }^{2} \\
\text { (Remodulin }^{\circledR}, \\
\text { Tresuvi }^{\circledR} \\
\text { Trepulmix }^{(}{ }^{\circledR} \text { ) }\end{array}$ & $\begin{array}{l}\text { Bioavailability: } 100 \% \\
\text { Metabolism: } \\
\text { Degradation in the liver } \\
\text { (primarily CYP2C8) } \\
\text { Elimination: } \\
\text { Mainly urine (79\%) } \\
\text { T } 1 / 22-4 \mathrm{~h}\end{array}$ & $\begin{array}{c}\text { Abscess } \\
\text { Bleeding/bruising } \\
\text { Infection (infusion } \\
\text { pump-related) } \\
\text { Malfunction of the } \\
\text { infusion pump } \\
\text { Pain } \\
\text { Other site reactions } \\
\text { (erythema, induration, } \\
\text { rash) }\end{array}$ & $\begin{array}{l}\text { Bleeding } \\
\text { Diarrhoea } \\
\text { Dizziness } \\
\text { Headache } \\
\text { Hypotension } \\
\text { Jaw pain } \\
\text { Nausea } \\
\text { Edema } \\
\text { Vomiting } \\
\text { Tachycardia } \\
\text { Vasodilatation }\end{array}$ \\
\hline & $\begin{array}{l}\text { i.v. infusion } \\
\text { (Remodulin }^{\circledR} \\
\text { Tresuvi }^{\circledR} \text { ) }\end{array}$ & $\begin{array}{l}\text { Bioavailability: } 100 \% \\
\text { Metabolism: } \\
\text { Degradation in the liver } \\
\text { (primarily CYP2C8) } \\
\text { Elimination: } \\
\text { Mainly urine (79\%) } \\
\text { T } 1 / 2 \text { 2-4 h }\end{array}$ & $\begin{array}{c}\text { Abscess } \\
\text { Bleeding/bruising } \\
\text { Infection } \\
\text { (catheter-related) } \\
\text { Malfunction of the } \\
\text { infusion pump } \\
\text { Pain } \\
\text { Sepsis } \\
\text { Thrombophlebitis } \\
\text { Other site reactions } \\
\text { (swelling, paraesthesia's, } \\
\text { erythema, induration, } \\
\text { rash) }\end{array}$ & \\
\hline & $\begin{array}{l}\text { Inhalation } \\
\left(\text { Tyvaso }^{\circledR}\right)\end{array}$ & $\begin{array}{c}\text { Bioavailability: } 64-72 \% \\
\text { Metabolism: } \\
\text { Degradation in the liver } \\
\text { (primarily CYP2C8) } \\
\text { Elimination: } \\
\text { Mainly urine (70\%) } \\
\text { T } 1 / 23-4 \mathrm{~h}\end{array}$ & $\begin{array}{c}\text { Cough } \\
\text { Epistaxis } \\
\text { Hemoptysis } \\
\text { Nasal discomfort throat } \\
\text { irritation } \\
\text { Throat pain } \\
\text { Wheezing }\end{array}$ & $\begin{array}{l}\text { Diarrhoea } \\
\text { Dizziness } \\
\text { Flushing } \\
\text { Headache } \\
\text { Nausea } \\
\text { Tachycardia } \\
\text { Vasodilatation }\end{array}$ \\
\hline & $\begin{array}{c}\text { p.o. } \\
\left.\text { (Orenitram }{ }^{\circledR}\right)\end{array}$ & $\begin{array}{c}\text { Bioavailability: } 17 \% \\
\text { Metabolism: } \\
\text { Degradation in the liver } \\
\text { (primarily CYP2C8) } \\
\text { Elimination: } \\
\text { Mainly urine }(70 \%) \\
\text { T } 1 / 21-1.5 \mathrm{~h}\end{array}$ & $\begin{array}{c}\text { Abdominal discomfort } \\
\text { Diarrhoea } \\
\text { Nausea } \\
\text { Vomiting }\end{array}$ & $\begin{array}{l}\text { Flushing } \\
\text { Headache } \\
\text { Jaw pain } \\
\text { Hypokalemia }\end{array}$ \\
\hline $\begin{array}{l}\text { lloprost } \\
\text { [55] }\end{array}$ & $\begin{array}{c}\text { Inhalation } \\
\text { (Ventavis }^{\circledR} \text { ) }\end{array}$ & $\begin{array}{c}\text { Bioavailability: } 63 \% \\
\text { Metabolism: } \\
\text { Oxidation in the liver } \\
\text { Elimination: } \\
\text { Mainly urine }(68 \%) \\
\text { T1 } 1220-30 \mathrm{~min}\end{array}$ & $\begin{array}{c}\text { Cough } \\
\text { Epistaxis } \\
\text { Hemoptysis } \\
\text { Nasal discomfort throat } \\
\text { irritation } \\
\text { Throat pain }\end{array}$ & $\begin{array}{l}\text { Diarrhoea } \\
\text { Dizziness } \\
\text { Flushing } \\
\text { Headache } \\
\text { Hypotension } \\
\text { Insomnia } \\
\text { Jaw pain } \\
\text { Nausea } \\
\text { Vomiting } \\
\text { Tachycardia } \\
\text { Vasodilatation }\end{array}$ \\
\hline $\begin{array}{l}\text { Beraprost } \\
{[56]}\end{array}$ & $\begin{array}{c}\text { p.o. } \\
\text { (Beraprost }^{\circledR} \text { ) }\end{array}$ & $\begin{array}{c}\text { Bioavailability: } 50-70 \% \\
\text { Metabolism: } \\
\text { Degradation in the liver } \\
\text { Elimination: } \\
\text { Mainly faeces (75\%) } \\
\text { T1 } 1230-40 \text { min }\end{array}$ & $\begin{array}{l}\text { Diarrhoea } \\
\text { Nausea }\end{array}$ & $\begin{array}{c}\text { Flushing } \\
\text { Headache } \\
\text { Increased bilirubin, } \\
\text { lactate dehydrogenase, } \\
\text { triglycerides }\end{array}$ \\
\hline $\begin{array}{l}\text { Selexipag } \\
{[34,57]}\end{array}$ & $\begin{array}{c}\text { p.o. } \\
\left(\text { Uptravi }^{\circledR}\right)\end{array}$ & $\begin{array}{l}\text { Bioavailability: } 49 \% \\
\text { Metabolism: } \\
\text { Hydrolysis in the liver } \\
\text { and intestine } \\
\text { (primarily CYP2C8) } \\
\text { Elimination: } \\
\text { Mainly feaces (93\%) } \\
\text { T1 } 123-4 \mathrm{~h}\end{array}$ & $\begin{array}{c}\text { Diarrhoea } \\
\text { Decreased appetite } \\
\text { Nausea } \\
\text { Vomiting }\end{array}$ & $\begin{array}{l}\text { Anaemia } \\
\text { Arthralgia } \\
\text { Headache } \\
\text { Hyperthyroidism } \\
\text { Flushing } \\
\text { Myalgia } \\
\text { Rash }\end{array}$ \\
\hline
\end{tabular}

${ }^{1}$ Contraindications to the use of any of the $\mathrm{PGI}_{2}$ analogues: heart failure with reduced left ventricular ejection fraction, severe hepatic impairment (Child Pugh class C), concomitant use of strong inhibitors of CYP2C8 (e.g. gemfibrozil), hypersensitivity to the drug; ${ }^{2}$ The preferred administration route of treprostinil; ${ }^{3}$ External or implantable intravenous infusion pump 


\section{Thrombosis and bleeding during prostacyclin and analogues therapy}

\section{Epoprostenol}

Epoprostenol not only inhibits platelet reactivity, but also decreases platelet count [26]. It was reported that epoprostenol induces thrombocytopenia in $35-65 \%$ of patients [27, 28]. Hence, bleeding complications may occur during treatment with epoprostenol. For example, among 31 patients with idiopathic PAH (iPAH), who were treated both with epoprostenol and anticoagulants, 11 bleeding episodes occurred (35\%), 9 of which were alveolar hemorrhages [29]. However, the concomitant anticoagulation may have biased the results. In a prospective, randomized, multicenter, open-label clinical trial which compared the efficacy of the continuous intravenous infusion of epoprostenol on top of conventional therapy versus conventional therapy alone in 81 patients with severe $\mathrm{PAH}$ (New York Heart Association [NYHA] class III or IV), 4 out of 41 patients treated with epoprostenol (9.8\%) experienced bleeding at the catheter site, and 1 experienced a thrombotic event (paradoxical embolism) [30]. However, the rate of bleeding and thrombotic events in the control group were not reported [30]. Herrero et al. [31] described 3 cases of severe PAH in pregnancy, treated with epoprostenol and complicated with thrombocytopenia, caesarean section wound hematoma and postpartum hemorrhage. Louis et al. [32] described 3 cases of nontraumatic subdural hematomas during treatment with $\mathrm{PGI}_{2}$ and analogues (1 with epoprostenol, 1 with iloprost and 1 with treprostinil). However, all episodes occurred in patients with low platelet count, and all patients received concomitant anticoagulantion, making it impossible to determine the real cause of bleeding events. Altogether, it seems that epoprostenol may increase the risk of bleeding. However, since the hitherto studies were prone to confounding factors such concomitant anticoagulation, lack of control group and small sample size, more research is needed to draw firm conclusions.

\section{Treprostinil}

In a prospective study including 860 patients with PAH treated with subcutaneous treprostinil with or without warfarin, the incidence of bleeding was 35\% (206/590) in patients on combined therapy, and $42 \%(112 / 270)$ in patients only receiving treprostinil (13 severe, 29 moderate and 70 mild bleeding episodes) [33, 34]. Similarly, in a double-blind, placebo-controlled, multicenter trial comprising 470 patients with $\mathrm{PAH}$, either idiopathic or associated with connective tissue disease or congenital heart disease, 34\% patients experienced infusion site bleeding or bruising with treprostinil (79/233), and as much as $44 \%$ with a placebo (102/236) during 12 weeks of treatment [35]. The incidence of gastrointestinal (GI) bleeding was only $0.01 \%(3 / 233)$ on treprostinil, and 2 out of 3 patients who experienced GI bleeding had increased international normalized ratio (INR; 3.1 and 4.0). In another study, the estimated incidence of GI bleeding with subcutaneous administration of treprostinil was $1.3 \%$ [36]. However, in a case series of 5 infants with PAH associated with chronic lung disease and treated with subcutaneous treprostinil, there were no bleeding or bruising episodes [37]. Altogether, although the treatment with subcutaneous treprostinil seems to be associated with relatively high rate of small and local bleeding, this rate was comparable to the placebo, which implies an effect of the infusion system, but not the drug itself. Recently, a double-blind, phase 3, randomised controlled trial was conducted, where 105 patients with chronic thromboembolic pulmonary hypertension, classified as non-operable, or with persistent or recurrent pulmonary hypertension after pulmonary endarterectomy, on chronic anticoagulation were divided into high-dose $(\sim 30 \mathrm{ng} / \mathrm{kg} /$ $/ \mathrm{min}, \mathrm{n}=53)$ and low-dose $(\sim 3 \mathrm{ng} / \mathrm{kg} / \mathrm{min}, \mathrm{n}=52)$ of subcutaneously administered treprostinil. There were no severe bleeding adverse events in the low dose group and single episodes of hemoptysis and hematoma in the high-dose group. Noteworthy, 3 (5.8\%) episodes of epistaxis were observed in the low-dose group, and only 1 (1.9\%) episode in the high-dose group, implying that the bleeding on subcutaneous treprostinil is not dose-related [38].

Besides subcutaneous infusion, which is the preferred administration route of treprostinil, it may also be administered intravenously. In a retrospective, multi-center study involving 12 patients with PAH treated with subcutaneous infusion of treprostinil, with intolerable pain at the infusion site, an intravenous infusion pump was implanted. During the postoperative period, 4 (33\%) patients experienced a small hematoma in the implantation site that required a single evacuation by puncture. In 1 patient, puncturing of the pump area was required 3 times due to a recurrence of the hematoma. However, this patient had concomitant coagulopathy due to splenomegaly associated with liver cirrhosis resulting in thrombocytopenia [39]. However, intravenous infusion might increase the bleeding risk, although no head-to-head compari- 
sons between the routes of treprostinil administration are available.

The efficacy and safety of inhaled treprostinil was evaluated in 9 patients with pulmonary hypertension and concomitant chronic obstructive pulmonary disease [40]. After 16 weeks of treatment, none of the patients experienced a clinically significant bleeding episode, and 1 patient reported blood in sputum [40]. Hence, it seems that treprostinil administered in inhalation may be safer than administered subcutaneously or intravenously, but the heterogeneity and small sample size of the study groups require caution when interpreting the results.

\section{Iloprost}

Intravenous iloprost was investigated in a prospective study in 30 patients with systemic sclerosis, leading to only 1 bleeding episode (intracranial hemorrhage) during 3 years follow-up. The same patient had previously suffered a central retinal vein thrombosis [41]. Intravenous iloprost was also evaluated in a randomized, placebo-controlled study in 300 patients as adjuvant to surgery for acute ischemia of lower limbs, with similar incidences of bleeding in patients treated with iloprost and placebo at 3 month follow-up [42]. Inhaled iloprost, in turn, was used to treat PAH due to preterm rupture of foetal membranes in 4 extremely low-birthweight neonates (23-25 weeks gestation, 448-645 gram weight) under spontaneous breathing, supported by nasal continuous positive airway pressure. There was no prolonged bleeding incident noted in any of the patients [43]. Altogether, it seems that both intravenous and inhaled iloprost may be safe, but there is too little data to draw firm conclusions.

\section{Beraprost}

In a prospective clinical trial comprising 308 patients with acute ischemic stroke, patients were divided into an experimental group $(\mathrm{n}=154)$ treated with beraprost ( $40 \mu \mathrm{g}$, twice daily) on top of acetylsalicylic acid (100 mg, once daily) and a control group $(n=154)$ treated with acetylsalicylic acid only (100 mg, once daily). Both treatment regimens were administered orally and continued for 6 months after hospital discharge. At 6 months, the coagulation parameters (activated partial thromboplastin time, prothrombin time, INR and fibrinogen) and bleeding rates were comparable between the groups [44]. Similarly, in a prospective clinical study including 55 patients with end-stage renal disease on hemodialysis, beraprost $(n=23,120 \mu g$ per day) did not increase the rate of bleeding, compared to the standard therapy $(n=32)$ [45]. Altogether, the preliminary data implicate that treatment with beraprost does not increase the rate of bleeding, but this conclusion needs to be confirmed in future studies.

\section{Selexipag}

The GRIPHON ( $\mathrm{PGI}_{2}$ Receptor Agonist In Pulmonary Arterial Hypertension) study took place in 181 centres and was the biggest clinical trial in patients with PAH. In this double-blind, randomized, placebo-controlled study, the efficacy and safety of selexipag was investigated in 1156 patients in different stadiums of PAH [21]. Selexipag did not increase the rate of bleeding, including gastrointestinal hemorrhage [46], and did not have a substantial effect on platelet aggregation [47]. Based on this study, selexipag seems to be a safe treatment regimen in $\mathrm{PAH}$.

\section{Discussion}

$\mathrm{PGI}_{2}$ and analogues are widely used in treatment of PAH, but their antiplatelet effect and related bleeding complications are still insufficiently investigated. Experimental data suggests that the IP and DP receptors have antiaggregatory effects, whereas the $\mathrm{TP}$ and $\mathrm{EP}_{3}$ have pro-aggregatory effects by modulating the intracellular concentration of cAMP [23-25, 48, 49]. Consequently, drugs which bind to the IP and DP receptors only (treprostinil, selexipag) are expected to have higher antiplatelet activity than those which bind to IP, DP and $\mathrm{EP}_{3}$ receptors (epoprostenol, beraprost) and to all receptors (iloprost). However, data from clinical studies do not always comply with experimental insights. For example, it seems that epoprostenol and treprostinil may increase bleeding risk, especially if treprostinil is administered subcutaneously or intravenously [33-35, 39]. In addition, a randomized controlled trial on 105 patients treated with treprostinil administered subcutaneously showed that the frequency of bleeding complications was not dose-related [38]. On the contrary, no increased bleeding tendency was seen with iloprost, beraprost and selexipag. Hence, one could consider avoiding epoprostenol and treprostinil, and rather choose iloprost, beraprost or selexipag in patients with increased bleeding risk, or with a history of bleeding. However, since the hitherto studies were prone to confounding factors such concomitant anticoagulation, lack of control group, small sample size and heterogeneity, the previous 
results should be interpreted with caution, and more evidence is needed to draw firm conclusions. Especially, large-scale, randomized clinical studies to compare different $\mathrm{PGI}_{2}$ analogues head-to-head are urgently needed to determine the optimal treatment regimen in patients with increased risk of thrombosis or bleeding, tailored to an individual patients' needs.

\section{Acknowledgments}

Aleksandra Gąsecka acknowledges funding from National Science Center, research program PRELUDIUM (2018/31/N/NZ7/02260).

\section{Conflict of interest: None declared}

\section{References}

1. Von Euler US. Über die Spezifische Blutdrucksenkende Substanz des Menschlichen Prostata- und Samenblasensekretes. Klin Wochenschr. 1935; 14(33): 1182-1183, doi: 10.1007/ /bf01778029.

2. The Nobel Prize. https://www.nobelprize.org/prizes/medicine/1982/press-release/ (Accessed: 7 April 2020).

3. Woodward DF, Jones RL, Narumiya S. International Union of Basic and Clinical Pharmacology. LXXXIII: classification of prostanoid receptors, updating 15 years of progress. Pharmacol Rev. 2011; 63(3): 471-538, doi: 10.1124/pr.110.003517, indexed in Pubmed: 21752876.

4. Mubarak KK. A review of prostaglandin analogs in the management of patients with pulmonary arterial hypertension. Respir Med. 2010; 104(1): 9-21, doi: 10.1016/j.rmed.2009.07.015, indexed in Pubmed: 19683911.

5. Safdar $Z$. Treatment of pulmonary arterial hypertension: the role of prostacyclin and prostaglandin analogs. Respir Med. 2011; 105(6): 818-827, doi: 10.1016/j.rmed.2010.12.018, indexed in Pubmed: 21273054.

6. Uptravi® Full Prescribing Information. https://www.uptravi.com/ assets/pdf/UPTRAVI-full-prescribing-information.pdf (Accessed 7 April 2020).

7. Heemskerk JWM, Bevers EM, Lindhout T. Platelet activation and blood coagulation. Thromb Haemost. 2002; 88(2): 186-193, indexed in Pubmed: 12195687.

8. Palta S, Saroa R, Palta A. Overview of the coagulation system. Indian J Anaesth. 2014; 58(5): 515-523, doi: 10.4103/00195049.144643, indexed in Pubmed: 25535411.

9. Winter WE, Flax SD, Harris NS. Coagulation testing in the core laboratory. Lab Med. 2017; 48(4): 295-313, doi: 10.1093/labmed/ Imx050, indexed in Pubmed: 29126301.

10. Lasne D, Jude B, Susen S. From normal to pathological hemostasis. Can J Anaesth. 2006; 53(6 Suppl): S2-11, doi: 10.1007/ BF03022247, indexed in Pubmed: 16766787.

11. Gomberg-Maitland M, Olschewski H. Prostacyclin therapies for the treatment of pulmonary arterial hypertension. Eur Respir J. 2008; 31(4): 891-901, doi: 10.1183/09031936.00097107, indexed in Pubmed: 18378784.

12. Armstrong RA. Platelet prostanoid receptors. Pharmacol Ther. 1996; 72(3): 171-191, doi: 10.1016/s0163-7258(96)00103-9, indexed in Pubmed: 9364574.
13. Boie Y, Sawyer N, Slipetz DM, et al. Molecular cloning and characterization of the human prostanoid DP receptor. J Biol Chem. 1995; 270(32): 18910-18916, doi: 10.1074/jbc.270.32.18910, indexed in Pubmed: 7642548.

14. Deep A, Zoha M, Dutta Kukreja P. Prostacyclin as an anticoagulant for continuous renal replacement therapy in children. Blood Purif. 2017; 43(4): 279-289, doi: 10.1159/000452754, indexed in Pubmed: 28118627.

15. Boie Y, Rushmore TH, Darmon-Goodwin A, et al. Cloning and expression of a cDNA for the human prostanoid IP receptor. J Biol Chem. 1994; 269(16): 12173-12178, indexed in Pubmed: 7512962 .

16. Berridge MJ. Inositol trisphosphate and calcium signaling. Nature. 1993; 361(6410): 315-325.

17. Hirata M, Hayashi $\mathrm{Y}$, Ushikubi F, et al. Cloning and expression of cDNA for a human thromboxane A2 receptor. Nature. 1991; 349(6310): 617-620, doi: 10.1038/349617a0, indexed in Pubmed: 1825698.

18. Nagy Z, Smolenski A. Cyclic nucleotide-dependent inhibitory signaling interweaves with activating pathways to determine platelet responses. Res Pract Thromb Haemost. 2018; 2(3): 558-571, doi: 10.1002/rth2.12122, indexed in Pubmed: 30046761.

19. Chakraborty R, Pydi SP, Gleim S, et al. New insights into structural determinants for prostanoid thromboxane $\mathrm{A} 2$ receptor- and prostacyclin receptor-G protein coupling. Mol Cell Biol. 2013; 33(2): 184-193, doi: 10.1128/MCB.00725-12, indexed in Pubmed: 23109431.

20. Kotani M, Tanaka I, Ogawa Y, et al. Structural organization of the human prostaglandin EP3 receptor subtype gene (PTGER3). Genomics. 1997; 40(3): 425-434, doi: 10.1006/geno.1996.4585, indexed in Pubmed: 9073510.

21. Sitbon O, Channick R, Chin K, et al. Selexipag for the Treatment of Pulmonary Arterial Hypertension. N Engl J Med. 2015; 373(26): 2522-2533, doi: 10.1056/nejmoa1503184.

22. Abramovitz M, Adam M, Boie Y, et al. The utilization of recombinant prostanoid receptors to determine the affinities and selectivities of prostaglandins and related analogs. Biochim Biophys Acta. 2000; 1483(2): 285-293, doi: 10.1016/s13881981(99)00164-x, indexed in Pubmed: 10634944.

23. Kiriyama M, Ushikubi F, Kobayashi T, et al. Ligand binding specificities of the eight types and subtypes of the mouse prostanoid receptors expressed in Chinese hamster ovary cells. $\mathrm{Br}$ J Pharmacol. 1997; 122(2): 217-224, doi: 10.1038/sj.bjp.0701367, indexed in Pubmed: 9313928.

24. Kuwano K, Hashino A, Asaki T, et al. 2-[4-[(5,6-diphenylpyrazin-2-yl)(isopropyl)amino]butoxy]-N-(methylsulfonyl)acetamide (NS-304), an orally available and long-acting prostacyclin receptor agonist prodrug. J Pharmacol Exp Ther. 2007; 322(3): 1181-1188, doi: 10.1124/jpet.107.124248, indexed in Pubmed: 17545310.

25. Whittle BJ, Silverstein AM, Mottola DM, et al. Binding and activity of the prostacyclin receptor (IP) agonists, treprostinil and iloprost, at human prostanoid receptors: treprostinil is a potent DP1 and EP2 agonist. Biochem Pharmacol. 2012; 84(1): 68-75, doi: 10.1016/j.bcp.2012.03.012, indexed in Pubmed: 22480736.

26. Gomberg-Maitland M, Tapson VF, Benza RL, et al. Transition from intravenous epoprostenol to intravenous treprostinil in pulmonary hypertension. Am J Respir Crit Care Med. 2005; 172(12): 1586-1589, doi: 10.1164/rccm.200505-7660C, indexed in Pubmed: 16151039.

27. Chin KM, Channick RN, de Lemos JA, et al. Hemodynamics and epoprostenol use are associated with thrombocytopenia in pul- 
monary arterial hypertension. Chest. 2009; 135(1): 130-136, doi: 10.1378/chest.08-1323, indexed in Pubmed: 18719056.

28. Hargett C, Ahearn G, Krichman A, et al. Thrombocytopenia associated with chronic intravenous epoprostenol therapy. Chest. 2004; 126(4), doi: 10.1378/chest.126.4_meetingabstracts.760s-b.

29. Ogawa A, Matsubara H, Fujio H, et al. Risk of alveolar hemorrhage in patients with primary pulmonary hypertension--anticoagulation and epoprostenol therapy. Circ J. 2005; 69(2): 216-220, doi: 10.1253/circj.69.216, indexed in Pubmed: 15671616.

30. Barst RJ, Rubin LJ, Long WA, et al. A comparison of continuous intravenous epoprostenol (prostacyclin) with conventional therapy for primary pulmonary hypertension. N Engl J Med. 1996; 334(5): 296-301, doi: 10.1056/NEJM199602013340504, indexed in Pubmed: 8532025.

31. Herrero T, Martin E, Poch DS, et al. Anti-coagulation complications in pregnancies with severe pulmonary arterial hypertension. J Matern Fetal Neonatal Med. 2018; 31(9): 1209-1213, doi: 10.1080/14767058.2017.1312329, indexed in Pubmed: 28353362.

32. Louis L, Bair N, Banjac S, et al. Subdural hematomas in pulmonary arterial hypertension patients treated with prostacyclin analogs [corrected]. Pulm Circ. 2012; 2(4): 518-521, doi: 10.4103/2045-8932.105041, indexed in Pubmed: 23372937.

33. Ascha M, Zhou X, Rao Y, et al. Impact on survival of warfarin in patients with pulmonary arterial hypertension receiving subcutaneous treprostinil. Cardiovasc Ther. 2017; 35(5), doi: 10.1111/1755-5922.12281, indexed in Pubmed: 28643420.

34. Barst RJ, Galie N, Naeije R, et al. Long-term outcome in pulmonary arterial hypertension patients treated with subcutaneous treprostinil. Eur Respir J. 2006; 28(6): 1195-1203, doi: 10.1183/09031936.06.00044406, indexed in Pubmed: 16899485.

35. Simonneau G, Barst RJ, Galie N, et al. Continuous subcutaneous infusion of treprostinil, a prostacyclin analogue, in patients with pulmonary arterial hypertension: a double-blind, randomized, placebo-controlled trial. Am J Respir Crit Care Med. 2002; 165(6): 800-804, doi: 10.1164/ajrccm.165.6.2106079, indexed in Pubmed: 11897647.

36. Mindus S, Pawlowski J, Nisell M, et al. Intra-abdominal bleeding during treprostinil infusion in a patient with pulmonary arterial hypertension. BMJ Case Rep. 2013; 2013, doi: 10.1136/bcr-2013008677, indexed in Pubmed: 23446048.

37. Ferdman DJ, Rosenzweig EB, Zuckerman WA, et al. Subcutaneous treprostinil for pulmonary hypertension in chronic lung disease of infancy. Pediatrics. 2014; 134(1): e274-e278, doi: 10.1542/peds.2013-2330, indexed in Pubmed: 24982101.

38. Sadushi-Kolici R, Jansa P, Kopec G, et al. Subcutaneous treprostinil for the treatment of severe non-operable chronic thromboembolic pulmonary hypertension (CTREPH): a double-blind, phase 3, randomised controlled trial. Lancet Respir Med. 2019; 7(3): 239-248, doi: 10.1016/ S2213-2600(18)30367-9, indexed in Pubmed: 30477763.

39. Kurzyna M, Małaczyńska-Rajpold K, Koteja A, et al. An implantable pump Lenus pro $\AA$ in the treatment of pulmonary arterial hypertension with intravenous treprostinil. BMC Pulm Med. 2017; 17(1): 162, doi: 10.1186/s12890-017-0474-7, indexed in Pubmed: 29195500.

40. Bajwa AA, Shujaat A, Patel M, et al. The safety and tolerability of inhaled treprostinil in patients with pulmonary hypertension and chronic obstructive pulmonary disease. Pulm Circ. 2017; 7(1): 82-88, doi: 10.1086/689291, indexed in Pubmed: 28680567.

41. Bettoni L, Geri A, Airò P, et al. Systemic sclerosis therapy with iloprost: a prospective observational study of 30 patients treated for a median of 3 years. Clin Rheumatol. 2002; 21(3): 244-250, doi: 10.1007/p100011223, indexed in Pubmed: 12111631.
42. de Donato G, Gussoni G, de Donato G, et al. The ILAILL study: iloprost as adjuvant to surgery for acute ischemia of lower limbs: a randomized, placebo-controlled, double-blind study by the italian society for vascular and endovascular surgery. Ann Surg. 2006; 244(2): 185-193, doi: 10.1097/01.sla.0000217555.49001.ca, indexed in Pubmed: 16858180.

43. Eifinger F, Sreeram N, Mehler K, et al. Aerosolized iloprost in the treatment of pulmonary hypertension in extremely preterm infants: a pilot study. Klin Padiatr. 2008; 220(2): 66-69, doi: 10.1055/s-2007-984370, indexed in Pubmed: 17710738.

44. Chen S, Xie S, He W, et al. Beneficial effect of beraprost sodium plus aspirin in the treatment of acute ischemic stroke. Med Sci Monit. 2017; 23: 4401-4407, doi: 10.12659/msm.902825, indexed in Pubmed: 28898204.

45. Kim M, Kim JiU, Kim SoMi, et al. Effectiveness of beraprost sodium in maintaining vascular access patency in patients on hemodialysis. Int Urol Nephrol. 2017; 49(7): 1287-1295, doi: 10.1007/s11255-017-1586-y, indexed in Pubmed: 28409403.

46. Krause A, Machacek M, Lott D, et al. Population Modeling of Selexipag Pharmacokinetics and Clinical Response Parameters in Patients With Pulmonary Arterial Hypertension. CPT Pharmacometrics Syst Pharmacol. 2017; 6(7): 477-485, doi: 10.1002/ /psp4.12202, indexed in Pubmed: 28556581.

47. Bruderer S, Hurst N, Kaufmann P, et al. Multiple-dose up-titration study to evaluate the safety, tolerability, pharmacokinetics, and pharmacodynamics of selexipag, an orally available selective prostacyclin receptor agonist, in healthy subjects. Pharmacology. 2014; 94(3-4): 148-156, doi: 10.1159/000367630, indexed in Pubmed: 25277144.

48. Stitham J, Arehart E, Gleim SR, et al. New insights into human prostacyclin receptor structure and function through natural and synthetic mutations of transmembrane charged residues. $\mathrm{Br}$ J Pharmacol. 2007; 152(4): 513-522, doi: 10.1038/sj.bjp.0707413, indexed in Pubmed: 17704830.

49. Wright DH, Metters KM, Abramovitz M, et al. Characterization of the recombinant human prostanoid DP receptor and identification of L-644,698, a novel selective DP agonist. Br J Pharmacol. 1998; 123(7): 1317-1324, doi: 10.1038/sj.bjp.0701708, indexed in Pubmed: 9579725.

50. Flolan ${ }^{\circledR}$ Full Prescribing Information. https://www.gsksource.com/ pharma/content/dam/GlaxoSmithKline/US/en/Prescribing_Information/Flolan/pdf/FLOLAN-PI-PIL.PDF (Accessed 7 April 2020).

51. Veletri® Full Prescribing Information. https://www.janssenlabels.com/package-insert/product-monograph/prescribing-information/VELETRI-pi.pdf (Accessed 7 April 2020).

52. Orenitram ${ }^{\circledR}$ Full Prescribing Information. https://www.orenitram.com/pdf/Orenitram_Full_Prescribing_Information.pdf (Accessed 7 April 2020).

53. Remodulin ${ }^{\circledR}$ Full Prescribing Information. https://www.remodulin.com/downloads/remodulin-prescribinginformation.pdf (Accessed 7 April 2020).

54. Tyvaso ${ }^{\circledR}$ Full Prescribing Information. https://www.tyvaso.com/ hcp/pdf/Tyvaso-PI.pdf (Accessed 7 April 2020).

55. Ventavis ${ }^{\circledR}$ Full Prescribing Information. https://www.4ventavis. com/pdf/Ventavis_PI.pdf (Accessed 7 April 2020).

56. Melian EB1, Goa KL. Beraprost: a review of its pharmacology and therapeutic efficacy in the treatment of peripheral arterial disease and pulmonary arterial hypertension. Drugs. 2002; 62(1): 107-133.

57. Kingman M, Archer-Chicko C, Bartlett M, et al. Management of prostacyclin side effects in adult patients with pulmonary arterial hypertension. Pulm Circ. 2017; 7(3): 598-608, doi: 10.1177/2045893217719250, indexed in Pubmed: 28632002. 